\title{
Transmembrane Protein 216
}

National Cancer Institute

\section{Source}

National Cancer Institute. Transmembrane Protein 216. NCI Thesaurus. Code C101663.

Transmembrane protein 216 (138 aa, $\sim 16 \mathrm{kDa}$ ) is encoded by the human TMEM216 gene. This protein is involved in cilium formation. 